\title{
EXPLORING THE RELATION BETWEEN THE INDEGREE CENTRALITY AND AUTHORITY SCORE OF A DECISION AND THE REASON FOR WHICH IT WAS CITED: A CASE STUDY ${ }^{1}$
}

\author{
by \\ TEREZIE SMEJKALOVÁ*, TEREZA NOVOTNÁ **
}

Some of the recent network citation analyses conducted in continental legal settings have suggested that the most cited decisions tend to be related to procedural issues, or issues of a more general nature. Such decisions are by nature capable of being referred to in a more varied situations, therefore scoring high in indegree centrality or authority score.

While it may seem intuitive that decisions with the highest indegree centrality or authority score would settle issues of a more general nature, hence making them more widely applicable to various kinds of subsequent cases, we were wondering, whether this trend would be noticeable in less exposed decisions. To this end, we have conducted a case study within the boundaries of the Czech legal system. We have chosen five decisions containing a chosen keyword based on their indegree centrality in a corpus of Czech apex courts' decisions. Subsequently, we have constructed eleven chains of decisions (connected to one another by a citation) leading to these five decisions, again paying attention to their indegree. We theorize that the decisions with higher indegree centrality as well as decisions with higher authority score will be cited in situations seeking a case-law argument for either procedural issue, or an issue of a more general nature, or an issue of principle, while the decisions with low indegree centrality or low authority score will be cited

1 This paper is a part of a project titled "Judikatura, nebo precedens: Podobnost citovaných rozhodnutí při citacích judikatury" (Project No. MUNI/A/0952/2019).

terezie.smejkalova@law.muni.cz, Department of Legal Theory, Faculy of Law, Masaryk University, Brno, Czech Republic.

** tereza.novotna@law.muni.cz, Institute of Law and Technology, Faculty of Law, Masaryk University, Brno, Czech Republic. 
for their substantive law merit. This paper seeks to demonstrate how the network analysis in combination with a qualitative approach may serve as a useful method in further exploring this hypothesis.

We show that the actual citation environment in Czech legal setting might be more complex than this hypothesis suggests and that this methodological approach may be further useful in exploring the normative nature of judicial decisions in non-precedential legal settings.

\section{KEY WORDS}

Judicial Decision, Centrality Network Analysis, Citation Analysis, Normative Nature of Case Law

\section{INTRODUCTION}

The question of whether or not do continental courts' decisions have any normative, or precedential, value has long been a part of legal discussions, attracting attention from numerous legal scholars. ${ }^{2}$ Recently, this question has been given a more quantitative attention, employing network analysis to use citations to past decisions as a tool to determine the courts' actual practice in this matter. ${ }^{3}$ Empirical data-driven research on theoretical legal concepts as well as various legal practices is one of the directions legal informatics follows recently. Despite that legal information retrieval is still more common direction in this field, with the development of advanced natural language processing techniques, legal scholars are capable of tackling some purely theoretical fundamental legal questions as well. Citation network analysis is a great example of a method used for both purposes. On the one hand, it serves well in, for example, providing data

\footnotetext{
Let us, for one noteable example, mention a comparative study of precedent across various jurisdictions edited by MacCormick, N., Summers, R. S. (eds.) (1997) Interpreting Precedents. A Comparative Study. Dartmouth: Aldershot.

3 See for example Fowler, J.H., Johnson, T.R., Spriggs, J.F., Jeon, S., Wahlbeck, P.J. (2007) Network Analysis and the Law: Measuring the Legal Importance of Precedents at the U.S. Supreme Court. Political Analysis, 15(3), pp. 324-346; Hitt, M. (2016) Measuring Precedent in Judicial Hierarchy. Law and Society Review, 50(1): pp. 57-81; Derlén, M. and Lindholm, J. (2017) Peek-a-Boo, It's a Case Law System! Comparing the European Court of Justice and the United States Supreme Court from a Network Perspective. German Law Journal, 18(3), pp. 647-686; Derlén, M. and Lindholm, J. (2014) Goodbye van Gend en Loos, Hello Bosman? Using Network Analysis to Measure the Importance of Individual CJEU. Judgments. European Law Journal, 20(5), pp. 667-687; or Derlén, M. and Lindholm, J. (2015) Characteristics of Precedent: The Case Law of the European Court of Justice in Three Dimensions. German Law Journal, 16(5), pp. 1073-1098.

Fowler et al. (2007) op. cit., pp. 324-346.
} 
suitable for court decisions retrieval and recommendation systems. ${ }^{4}$ On the other hand, it is commonly used for finding out how the judicial systems work in general. Specifically, citation analysis can help understand abstract legal concepts such as relevance or importance of court decisions as well as citation practice of different courts and judges.

Until very recently, the Czech citation practices have remained empirically unexplored. ${ }^{5}$ The classical doctrinal approach yielded no fixed agreement on the normative nature of past judicial decisions for subsequent decision-making, often settling on conclusions that while the decisions are not precedents in the common law sense, they have some sort of fluid normative value. ${ }^{6}$ However, the analyses of judicial decisions often use concepts borrowed from the doctrine of binding precedent (such as ratio decidendi and obiter dictum), with one notable exception: the requirement of similarity of the facts of the cases.

Ignoring questions of fact may lead to decontextualized use of case law, where a case is cited not because its facts are similar and it has a recognizable precedential value, but just because it contains something loosely legally related to the decision in which it is cited. There have been voices criticising this decontextualized approach in the use of case law in judicial decision-making, usually citing the (risk of) infringement of the separation of powers thesis, and - in consequence - diluting the legitimacy of such judicial decision making. ${ }^{7}$ Should we put together this practice together with the prevalent opinion that citing past case law is somewhat bordering on good manners ${ }^{8}$ an environment is created that encourages citing any past judicial decision relevant to any legal issue

4 For example, legal information systems employ features recommending decisions cited in certain decision, or a citation index of a decision is used as a measure determining its importance and its position in list of results when searching for relevant court decisions.

5 This has been changed by research published in Harašta, J., Smejkalová, T., Novotná, T. et al. (2021) Citační analýza judikatury. Praha: Wolters Kluwer. This publication brings the overview of the Czech apex courts' citation practice, concluding that while it is very far from precedent, the research suggests development to some sort of weak principle of stare decisis. See Harašta, Smejkalová, Novotná et al. (2021) op. cit., pp. 225-233.

6 See Bobek, M., Kühn, Z. et al. Judikatura a právní argumentace. 2nd edition. Praha: Auditorium, 2013.

7 See e.g. Smejkalova, T. (2019) Judikatura, nebo precedens? Právník, 158(9), pp. 852-864; Polčák, R. (2012) Internet a proměny práva. Praha: Auditorium, p. 228-232; or David, L. (2008) Co je precedent v rozhodnutích českých civilních soudů? In: Dny práva - 2008 - Days of Law. Brno: Tribun EU [online]. 2008 [accesseed 1.2.2013]. Available from http://www.law.muni.cz/sborniky/dp08/files/pdf/prteorie/david.pdf.

8 Currently, around $70 \%$ of decisions by Czech apex courts contain at least one reference to past judicial decision. See Harašta, J., Smejkalová, T., Novotná, T. et al. (2021) op. cit., pp. 165-178. 
the decision tackles, including the ones related to general issues of principle, or procedure. Moreover, a suggestion was made by a study within the Dutch legal environment ${ }^{9}$ that the judicial decisions more frequently cited by other decisions are cited because of an issue of a procedural or a more general nature.

We have designed a study to explore this suggestion further. We have used network analysis to construct a number of chains of decisions that were further analysed in terms of their content. These chains were chosen based on the indegree centrality of the decisions which allowed us to explore the claim above, that the judicial decisions more frequently cited by other decisions are cited because of an issue of a procedural or a more general nature. It also allows us to explore, whether it does, in turn, suggest that decisions with low indegree centrality would be cited rather for substantive law reasons.

To explore these hypotheses, we have analysed the chains of citations, categorized the citation occurrences and compared them not only to the indegree centrality but also to the authority score of cited decision. We show that while in our sample the decisions with high indegree centrality and high authority scores do, indeed, tend to be cited for procedural, or unquestionably general, reasons, the opposite side of this hypothesis points towards a more complicated reality. While this article must be seen as a proof of concept case study and while its limited scope does not allow us to generalize on our findings, it suggests that the actual citation environment in Czech legal setting (and likely in other continental legal settings sharing basic systemic similarities ${ }^{10}$ ) might be more complex than the hypotheses suggest.

\section{THEORY OVERVIEW}

Recent studies employing network analysis ${ }^{11}$ of citations of judicial decisions usually rely on simple operationalizations of citations of judicial decisions as an indicator of some sort of relevance, ${ }^{12}$ importance, ${ }^{13}$ noteworthiness ${ }^{14}$ etc. of such a decision in the legal system, usually connecting it with

\footnotetext{
Winkels, R. and Ruyter, J. (2012) Survival of the Fittest: Network Analysis of Dutch Supreme Court Cases. In: Palmirani, M. et al. (eds.) AICOL Workshops 2011. Heidleberg: Springer Verlag, pp. 106-115.

10 The Czech legal system is said to belong to the "Germanic" family within the continental law tradition. Our discussion and conclusions might not be transferrable to differing continental jurisdictions, notably to the French one, that does not allow judges to rely on previous case law at all. See Art. 5 of Code Civil.
} 
network of measures of degree centrality, ${ }^{15}$ eigenvector centrality or more complex measures based on iterative algorithms (authority and hub score). ${ }^{16}$ These methods - developed in the context of precedential legal systems have been used in continental legal systems with varied results. ${ }^{17}$

The number of times a decision is cited (which in network analysis terms corresponds to its indegree centrality) may be intuitively seen as an indicator of a decision's prominence in the network and, consequently, the legal system as a whole. Fowler et al., ${ }^{18}$ Fowler and Jeon ${ }^{19}$ and Whale ${ }^{20}$ have shown that it is oversimplified and cannot by itself grasp the complexities of the judicial decision-making. For this reason, Fowler et al., Fowler and Jeon, and in continental legal settings for example Derlén and Lindholm ${ }^{21}$ make use of authority and hub scores. ${ }^{22}$

It may seem tempting to use these metrics to determine relevance of a judicial decision and explore employing them in legal information retrieval systems. Citation analysis is commonly used to retrieve legally

11 Network analysis is a set of techniques based on network and graph theories. It is based on an assumption that various social phenomena (such as judicial decisions in our case) are linked together by various relationships (in our case citations). Analysis of these relationships and their structures is capable of bringing new information about the network as a whole. For detailed explanation see Brandes, U. and Erlebach, T. (eds.) (2005) Network Analysis. Methodological Foundations, Heidelberg: Springer.

12 Black, R.C. and Spriggs, J.F. II. (2013) The Citation and Depreciation of U.S. Supreme Court Precedent. Journal of Empirical Legal Studies. 10(2), pp. 325-358.

13 Fowler, J.H., Johnson, T.R., Spriggs, J.F., Jeon, S., Wahlbeck, P.J. (2007) Network Analysis and the Law: Measuring the Legal Importance of Precedents at the U.S. Supreme Court. Political Analysis, 15(3), pp. 324-346.

14 Hitt, M. (2016) Measuring Precedent in Judicial Hierarchy. Law and Society Review, 50(1): pp. 57-81.

15 See Fowler et al. (2007) op. cit., pp. 324-346, or Fowler, J. and Jeon, S. (2008) The Authority of Supreme Court precedent. Social Networks, 30, pp.16-30.

16 See Fowler et al. (2007) op. cit., pp. 324-346 or Fowler and Jeon (2008) op. cit., pp. 16-30.

17 Derlén, M. and Lindholm, J. (2017) Peek-a-Boo, It's a Case Law System! Comparing the European Court of Justice and the United States Supreme Court from a Network Perspective. German Law Journal, 18(3), pp. 647-686; Derlén, M. and Lindholm, J. (2014) Goodbye van Gend en Loos, Hello Bosman? Using Network Analysis to Measure the Importance of Individual CJEU. Judgments. European Law Journal, 20(5), pp. 667-687; or Derlén, M. and Lindholm, J. (2015) Characteristics of Precedent: The Case Law of the European Court of Justice in Three Dimensions. German Law Journal, 16(5), pp. 10731098.

18 Fowler et al. (2007) op. cit., pp. 324-346.

19 Fowler and Jeon (2008) op. cit., pp. 16-30.

20 Whalen, R. (2013) Modelling Annual Supreme Court Influence: The Role of Citation Practices and Judicial Tenure in Determining Precedent Network Growth. In: Menzes, R., Evsukoff, A., Gonzales, M.C. (eds.) Complex Networks. Studies in Computational Intelligence. Berlin, Heidelberg: Springer, pp. 169-176, p. 269.

21 Derlén and Lindholm (2017) op. cit., pp. 647-686.

22 Authority and hub scores are based on Kleinberg's iterative algorithms - HITS. See Kleinberg, J. M. (1998) Authoritative sources in a hyperlinked environment. In: Proceedings of ACM-SIAM Symposium on Discrete Algorithms 1998, pp. 668-677. 
relevant court decisions in recommendation systems. Wagh and Anand showed that decisions connected by citations are more similar than decisions similar according to the cosine similarity. ${ }^{23}$

However, there have been voices who disputed the automatic borrowing of these operationalizations from studies in precedential legal systems and using them in continental legal setting. ${ }^{24}$ While the results of Derlén and Lindholm's research suggest similarity in network patterns between the decision-making practice of the Supreme Court of the United States, ${ }^{25}$ the underlying processes leading to overt similarities in network patterns are not the same.

Before building any concepts of relevance or importance of a decision in a system in continental legal settings on indegree centrality or authority score, more research needs to be undertaken.

Winkels and de Ruyter, who explored the citation environment of the Dutch Supreme Court found out that most of the most cited cases are - unsurprisingly - of a procedural nature. ${ }^{26}$ While they do not elaborate on this point further, a recent research related to the citation environment of apex courts in the Czech Republic ${ }^{27}$ agrees that in continental legal settings, this is, indeed, unsurprising as most apex courts, such as Supreme Courts or Constitutional Courts often do not resolve questions of fact, they focus on questions of law, usually those having wider impact on the legal system, not only to the individual claimants. The questions of law often tend to be related to issues of procedure, court competence, or more general

${ }^{23}$ Wagh, R., Anand, D. (2017). Application of citation network analysis for improved similarity index estimation of legal case documents: A study. 2017 IEEE International Conference on Current Trends in Advanced Computing (ICCTAC), 1-5. https://doi.org/10.1109/ICCTAC.2017.8249996.

24 Frankenreiter, J. (2017) Network Analysis and the Use of Precedent in the Case Law of the CJEU - A Reply to Derlén and Lindholm. German Law Journal, 18(3), p. 687- 693 and Petersen, N. and Towfigh, E. V. (2017) Network Analysis and Legal Scholarship. 18 German Law Journal, 18(3), p. 695-700 critically discussed Derlén and Lindholm's conclusions about a "precedential" nature of the decision-making practice of Court of Justice of the European Union. See Derlén, M. and Lindholm, J. (2017) Peek-a-Boo, It's a Case Law System! Comparing the European Court of Justice and the United States Supreme Court from a Network Perspective. German Law Journal, 18(3), pp. 647-686. Recently, this critique has also been voiced in Harašta, J., Smejkalová, T., Novotná, T. et al. (2021) Citační analýza judikatury. Praha: Wolters Kluwer. In addition, for a recent analysis of an alternative framework to approach both precedential as well non-precedential legal systems see Smejkalová (2020) op. cit.

25 See Derlén and Lindholm (2017) op. cit.

26 Winkels and de Ruyter (2012) op. cit., pp. 106-115.

27 Harašta, J., Smejkalová, T., Novotná, T. et al. (2021) Citační analýza judikatury. Praha: Wolters Kluwer. 
questions of principle (such as in the case of a court deciding upon constitutionality of individual legal rules).

However, we should note that since we are dealing with law and individual legal systems more elements of a given legal system may be at play, especially the role of their supreme courts. For example, research within the Italian legal system has shown that the above link between the number of times a decision was cited and the substantive/procedural nature of the cited case might not necessarily be generally applicable as the most cited cases are rather of substantive, not procedural nature. ${ }^{28}$

Moreover, the details on how to use past case-law in judicial decision-making in continental legal settings differ from system to system, ranging from a prohibition ${ }^{29}$ to overt resemblance of a precedential system. ${ }^{30}$ Insystems, where the role of case law seems to be rather fluid, such as the Czech legal system, the textbooks usually try to paint a picture of a continental type of case-law - 'judikatura' - as something different from precedent. ${ }^{31}$ Nevertheless, the theory borrows doctrine-of-precedent terms such as ratio decidendi or obiter dictum, making 'judikatura' seem conceptually closely related to precedent. However, the most notable difference between the way continental legal systems - and the Czech system, within which we have conducted present research - handle the case-law is the (possibly seeming?) omission of the similarity of facts as a condition for a precedent's applicability. ${ }^{32}$

Therefore, a part of the goal of this paper is to shed more light onto the question as to what extent we can or cannot utilise the same operationalisations in citation analysis in continental legal system as in presidential systems, given the specifics and possible differences between individual legal systems.

In a system where judges are not compelled to consider the factual similarity between cases, they tend to use past case law as something between a legal rule and doctrine (or jurisprudence), subjecting it

28 See e.g. Agnoloni, T., Pagallo, U. (2015) The case law of the Italian constitutional court, its power laws, and the web of scholarly opinions. In: ICAIL'15: 15th International Conference on Artificial Intelligence and Law, pp. 151-155, or Agnoloni, T. Pagallo, U. (2015) The Power Laws of the Italian Constitutional Court, and Their Relevance for Legal Scholars. In: Legal Knowledge and Information Systems. pp. 1-10.

29 Such as in the context of Article 5 of Code Civil in case of French legal system.

30 Such as the practice of the Court of Justice of the European Union.

31 Harvánek, J. et al. (2008) Teorie práva. Plzeň: Vydavatelství a nakladatelství Aleš Čeněk, p. 250.

32 Smejkalová, T. (2019) Judikatura, nebo precedens? Právník. 158(9), pp. 852-864. 
to interpretation, and focusing on general coherence of the legal system. ${ }^{33}$ Therefore, it is not surprising that within such a legal setting, the more general or procedural issue the decision solves or the more important legal principle it helps to paint, the more appealing it might be for other judges to call upon those decisions in their own decision-making. Simply said, the more general the decision, the more likely it is to be prominent in the legal system. ${ }^{34}$ Or, in network analysis terms, the higher indegree centrality - or authority score (measures based on the inward citations of the decision) - the decision might have. Consequently, this might mean that in continental legal settings courts may refer to such a general decision even in situations that are not factually similar with the case decided by the general decision and could not strictly be called 'precedents'. It is not clear, however, whether the opposite would be the case, i.e. tendency to choose less-cited decisions for substantive law reasons and in factually similar situations.

\section{METHODOLOGY AND DATA}

We have designed a proof-of-concept case study that allows us to test this assumption and to determine whether the lower indegree centrality (and authority score) decisions tend to be cited for substantive law reasons in factually similar situations.

We closely build upon a previous study that constructed and analysed a network of judicial decisions of Czech apex courts. Technical details of the network analysis and its parameters are, therefore, reported

33 See e.g. Araszkiewicz, M., Šavelka, J. (eds.) Coherence: Insights from Philosophy, Jurisprudence and Artificial Intelligence. Heidleberg: Springer; or in the Czech legal context Smejkalová, T. A Matter of Coherence. In: Araszkiewicz, M., Myška, M., Smejkalová, T., Šavelka, J., Škop, M. (eds.) Law and Literature. Argumentation 2012 Workshop Proceedings. Brno: Masarykova univerzita, pp. 31-44.

34 It must be noted that this is by no means the only factor determining the decision's prominence in the system, nor its normative value of any kind, see MacCormick, N., Summers, R. S. (eds.) (1997) Interpreting Precedents. A Comparative Study. Dartmouth: Aldershot; in Czech legal context see Kühn, Z. (2001) Nová koncepce normativity judikatury obecného soudnictví na pozadí rozhodnutí Ustavního soudu. Právní rozhledy, (6), pp. $265-269$, nor the reason and circumstances why it was chosen to be cited in another judicial decision. This question has been discussed in more detail by Smejkalová, T. (2020) Importance of judicial decisions as a perceived level of relevance. Utrecht Law Review, 16 (1): pp. 39-56. doi:10.36633/ulr.504. 
elsewhere. ${ }^{35}$ For the purpose of this study, we used two outputs of this previous analysis: indegree centrality ${ }^{36}$ and authority score. ${ }^{37}$

The indegree centrality was the criterion used to construct 11 chains of decisions leading to 5 different decisions containing the keyword ('azyl', eng. 'asylum') within the network of decisions within the corpus of Czech apex courts decisions. ${ }^{38}$

The first three decisions have the highest indegree centrality of all the decisions in the corpus containing the chosen keyword, the fourth one's indegree corresponds to the mean value, the fifth's indegree to the median value of indegree of all the decisions in the corpus containing the chosen keyword.

To construct the chains of decisions, these decisions formed Level 1 in our chain construction. To each of these decisions we have determined the set of all the decisions within the corpus that contained a citation to Level 1 decision. These decisions formed Level 2 in our chain. Consequently, we have determined the set of all the decisions within the corpus that contained a citation to at least one Level 2 decisions. We have repeated this process until we had five such levels. The construction scheme for our chains is illustrated in Figure 1.

As mentioned above, the decisions for each of the chains were chosen from individual levels based on their own indegree centrality: one of the chains led through decisions with maximum indegree decisions on each level, one led through median indegree decisions on each level, one led through minimum indegree decisions on each level. ${ }^{39}$ Therefore, there are three chains leading to each one of the first three Level 1 decisions. Given the diminishing number of decisions at each level, there is only one

35 Harašta, Smejkalová, Novotná et al. (2021) op. cit.

36 The indegree centrality of a decision refers to the number of inward citations, i.e. the number of links leading to this decision.

37 Authority score is based on connecting the meaning of both inward and outward citations in a more complex manner by means of an iterative algorithm. In Kleinberg's words, "[hubs] and authorities exhibit what could be called a mutually reinforcing relationship: a good hub is a [node] that points to many good authorities; a good authority is a [node] that is pointed to by many good hubs." See Kleinberg (1998) op. cit.

38 Harašta, J., Novotná, T., Šavelka, J. (2020) Citation Data of Czech Apex Courts : arXiv:2002.02224, ISSN 2331-8422, available from: https://github.com/czech-case-lawrelevance/czech-court-citations-dataset.

39 Where there were more than one decision with the same median or minimum indegree value, we have chosen a decision at random. 
chain to each of the fourth and fifth Level 1 decisions, both leading through median indegree centrality value decisions on each level. ${ }^{40}$

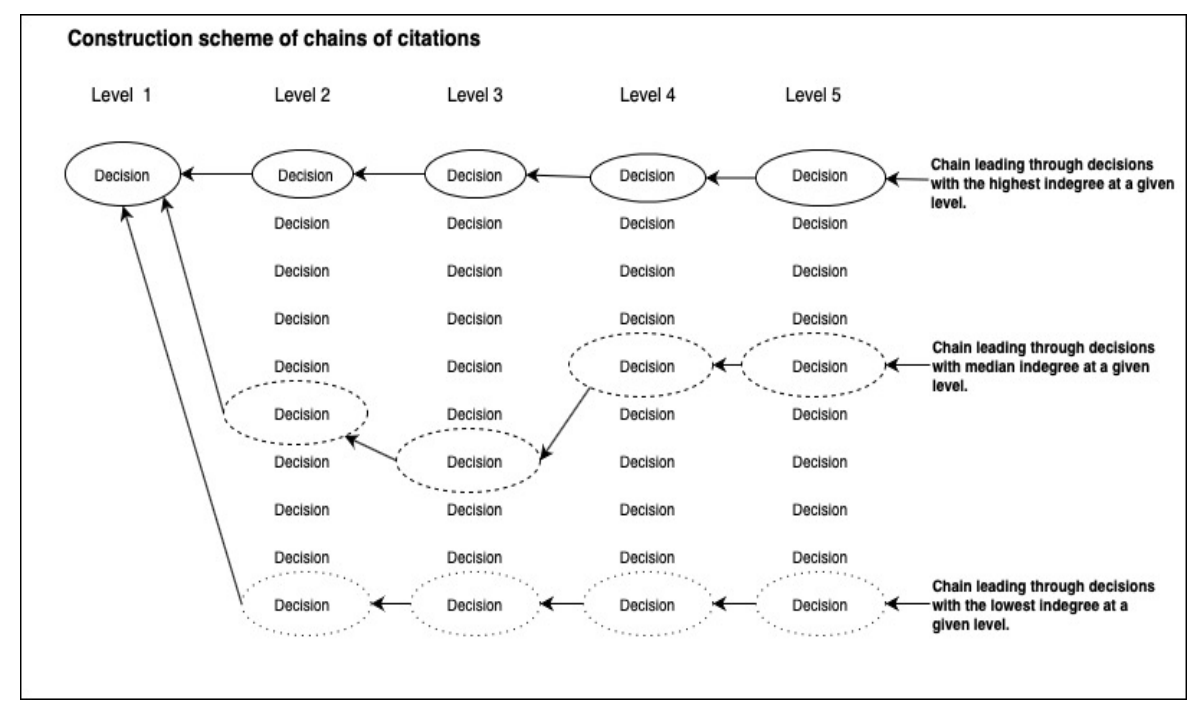

Figure 1. Construction scheme of citation chains

In short, in each chain of decisions, the one on lower level cites the one on the upper level, leading all the way to a given Level 1 decision. Within these chains, there are forty-four edges (links) - citations leading from lower level decision to upper level decision - which are relevant to our analysis.

The following Table 1 provides an overview of the chains and individual decisions for reference. ${ }^{41}$

40 Sometimes a decision in these chains was cited by only one or two other decisions, which mean that a chain based on maximum indegree centrality decisions would look practically the same as a chain based on median value. We have chosen median to capture at least an attempt at a middle route.

41 The decisions are listed under their file designations. Given our choice of keyword, most of the decisions were made by the Supreme Administrative Court of the Czech Republic, 6 decisions were made by the Constitutional Court of the Czech Republic and 3 decisions were made by the Supreme Court of the Czech Republic. For the purpose of the tables, "Route" means the indegree centrality value for which each of the decisions were chosen from their individual levels. When there were more decisions with the same indegree centrality on a given level, a random decision was chosen. 


\begin{tabular}{|c|c|c|c|c|c|c|}
\hline $\begin{array}{c}\text { Chain } \\
\text { designation }\end{array}$ & Level 1 & Route & Level 2 & Level 3 & Level 4 & Level 5 \\
\hline Asylum 1 & 1 Azs 13/2006 - 39 & $\begin{array}{l}\text { Max } \\
\text { Med } \\
\text { Min }\end{array}$ & $\begin{array}{l}3 \text { Azs } 89 / 2007 \\
3 \text { Azs 35/2006 } \\
1 \text { Azs } 43 / 2009\end{array}$ & $\begin{array}{l}8 \text { Azs } 23 / 2008 \\
7 \text { Ans } 15 / 2012 \\
3 \text { Azs } 29 / 2010\end{array}$ & $\begin{array}{c}5 \text { Azs } 74 / 2008 \\
29 \text { Cdo } 5069 / 2015 \\
3 \text { Azs } 6 / 2011\end{array}$ & $\begin{array}{c}5 \text { Azs } 66 / 2008 \\
33 \text { Cdo } 4050 / 2016 \\
4 \text { Azs } 3 / 2012\end{array}$ \\
\hline \multirow[t]{3}{*}{ Asylum 2} & 3 Azs 33/2004-98 & Max & 1 As $9 / 2009$ & Pl. ÚS 17/10-2 & I. ÚS 4019/13 & I. ÚS 1565/14 \\
\hline & & Med & 8 Aps $8 / 2007$ & 6 Afs $46 / 2014$ & 2 Ads $126 / 2014$ & 2 As $107 / 2017$ \\
\hline & & Min & $\begin{array}{c}6 \text { Ads } \\
113 / 2009\end{array}$ & 7 Afs $1 / 2007$ & 5 Azs 248/2017 & 10 Azs16/2017 \\
\hline \multirow[t]{3}{*}{ Asylum 3} & 2 Azs 92/2005 - 58 & Max & 2 As $69 / 2008$ & IV. ÚS 2170/08 & III. ÚS 1976/09 & Pl. ÚS 29/11 \\
\hline & & Med & 4 As 3/2008 & 1 Ans $7 / 2012$ & 1 Afs $362 / 2016$ & 7 Afs $68 / 2017$ \\
\hline & & Min & 4 As $3 / 2008$ & 2 As $97 / 2016$ & 1 As $343 / 2017$ & $28 \mathrm{Cdo} 729 / 2018$ \\
\hline $\begin{array}{l}\text { Asylum } \\
\text { Mean }\end{array}$ & 3 Azs 77/2004 & Med & 5 Azs 6/2010 & 7 Azs 79/2009 & 3 Azs 56/2012 & 2 Azs 220/2014 \\
\hline $\begin{array}{l}\text { Asylum } \\
\text { Median }\end{array}$ & 3 As $84 / 2013$ & Med & 5 Azs 209/2016 & 2 Azs $273 / 2016$ & 2 Azs 331/2017 & 2 Azs $365 / 2017$ \\
\hline
\end{tabular}

Table 1: Overview of case file designations of decisions in each chain of decisions.

Table 2 shows the indegree centrality and Table 3 the authority scores of each of the decisions in the chains. For clarity, in the following text we will use special designations when talking about individual decisions. The five original decisions are referred to as Asylum 1, 2, 3, Mean and Median, depending on their indegree centrality. The chains are leading either through the decisions with the highest (max), median (med) or lowest (min) indegree centrality on a given level. Individual decisions will always be referred to by their level and chain designation. For example, decision 3 Azs 89/2007 will be referred to as Asylum 1 max Level 2 decision.

\begin{tabular}{|c|c|c|c|c|c|c|}
\hline Chain designation & Level 1 & Route & Level 2 & Level 3 & Level 4 & Level 5 \\
\hline \multirow[t]{3}{*}{ Asylum 1} & 1991 & Max & 30 & 33 & 5 & 186 \\
\hline & & Med & 42 & 5 & 12 & 0 \\
\hline & & Min & 15 & 4 & 63 & 0 \\
\hline \multirow[t]{3}{*}{ Asylum 2} & 589 & Max & 5 & 44 & 20 & 79 \\
\hline & & Med & 10 & 12 & 3 & 0 \\
\hline & & Min & 11 & 130 & 2 & 0 \\
\hline \multirow[t]{3}{*}{ Asylum 3} & 492 & $\operatorname{Max}$ & 23 & 52 & 18 & 1362 \\
\hline & & Med & 332 & 1 & 4 & 0 \\
\hline & & Min & 332 & 3 & 1 & 0 \\
\hline Asylum Mean & 9 & Med & 60 & 131 & 3 & 0 \\
\hline Asylum Median & 2 & Med & 2 & 3 & 4 & 1 \\
\hline
\end{tabular}

Table 2: Indegree centrality of individual decisions ${ }^{42}$

42 Indegree centrality refers to the decision's indegree centrality in the whole corpus referred to above. 


\begin{tabular}{|c|c|c|c|c|c|}
\hline \multicolumn{3}{|c|}{ High authority score } & \multicolumn{3}{|c|}{ Low authority score } \\
\hline Place in chain & Decision designation & $\begin{array}{c}\text { Authority } \\
\text { score }\end{array}$ & Place in chain & $\begin{array}{c}\text { Decision } \\
\text { designation }\end{array}$ & Authority score \\
\hline Asylum 1 Level 1 & 1 Azs 13/2006 - 39 & $1,9 \cdot 10-5$ & $\begin{array}{l}\text { Asylum mean } \\
\text { Level } 1\end{array}$ & 3 Azs 77/2004-86 & $8,2 \cdot 10-9$ \\
\hline $\begin{array}{l}\text { Asylum } 3 \text { min } \\
\text { Level } 2\end{array}$ & 4 As $3 / 2008-78$ & $1,5 \cdot 10-5$ & $\begin{array}{c}\text { Asylum } 3 \text { min } \\
\text { Level } 3\end{array}$ & 2 As $97 / 2016$ & $3,1 \cdot 10-9$ \\
\hline $\begin{array}{c}\text { Asylum } 3 \text { med } \\
\text { Level } 2 \\
\end{array}$ & 4 As 3/2008 - 78 & $1,5 \cdot 10-5$ & $\begin{array}{c}\text { Asylum } 1 \text { med } \\
\text { Level } 4 \\
\end{array}$ & 29 Cdo 5069/2015 & $3,0 \cdot 10-9$ \\
\hline Asylum 3 Level 1 & 2 Azs 92/2005 - 58 & $1,3 \cdot 10-5$ & $\begin{array}{c}\text { Asylum } 2 \text { min } \\
\text { Level } 2 \\
\end{array}$ & 6 Ads 113/2009 - 43 & $2,6 \cdot 10-9$ \\
\hline $\begin{array}{l}\text { Asylum mean } \\
\text { Level } 3\end{array}$ & 7 Azs 79/2009 - 84 & $5,2 \cdot 10-6$ & $\begin{array}{c}\text { Asylum } 1 \text { med } \\
\text { Level } 3\end{array}$ & 7 Ans 15/2012 - 15 & $2,0 \cdot 10-9$ \\
\hline $\begin{array}{c}\text { Asylum } 3 \text { max } \\
\text { Level } 3\end{array}$ & IV. ÚS 2170/08-1 & $4,6 \cdot 10-6$ & $\begin{array}{c}\text { Asylum } 1 \mathrm{~min} \\
\text { Level } 3\end{array}$ & 3 Azs 29/2010 - 63 & $1,7 \cdot 10-10$ \\
\hline $\begin{array}{c}\text { Asylum } 3 \text { max } \\
\text { Level } 4\end{array}$ & III. ÚS 1976/09-1 & $4,0 \cdot 10-6$ & $\begin{array}{c}\text { Asylum median } \\
\text { Level } 1\end{array}$ & 3 As $84 / 2013$ & $1,6 \cdot 10-10$ \\
\hline Asylum 2 Level 1 & 3 Azs 33/2004-98 & $1,9 \cdot 10-6$ & $\begin{array}{c}\text { Asylum } 1 \text { max } \\
\text { Level } 4\end{array}$ & 5 Azs 74/2008 - 88 & $9,6 \cdot 10-10$ \\
\hline $\begin{array}{c}\text { Asylum } 1 \text { med } \\
\text { Level } 2\end{array}$ & 3 Azs 35/2006 - 104 & $1,4 \cdot 10-6$ & $\begin{array}{c}\text { Asylum } 3 \text { med } \\
\text { Level } 4 \\
\end{array}$ & 1 Afs $362 / 2016-36$ & $9,2 \cdot 10-10$ \\
\hline \multirow[t]{3}{*}{$\begin{array}{c}\text { Asylum } 2 \text { med } \\
\text { Level } 2 \\
\end{array}$} & 8 Aps 8/2007-90 & $1,3 \cdot 10-6$ & $\begin{array}{c}\text { Asylum } 3 \text { med } \\
\text { Level } 3 \\
\end{array}$ & 1 Ans 7/2012 - 43 & $3,5 \cdot 10-10$ \\
\hline & & & $\begin{array}{c}\text { Asylum } 2 \text { min } \\
\text { Level } 4\end{array}$ & 5 Azs 248/2017 - 35 & $7,0 \cdot 10-11$ \\
\hline & & & $\begin{array}{c}\text { Asylum } 3 \text { min } \\
\text { Level } 4\end{array}$ & 1 As $343 / 2017$ & $4,0 \cdot 10-11$ \\
\hline
\end{tabular}

Table 3: Authority score of individual decisions in order from the highest to the lowest ${ }^{43}$

All the texts of all the decisions in these chains were subsequently analyzed with special attention to the facts of the case of each decision and the individual context - procedural/general or substantive - for which it was cited by a decision on a lower level. Based on what has been explained above, we have sought to explore the following hypothetic tendencies within our 11 citation chains:

Hypothesis 1a: Decisions with higher indegree centrality are cited for their procedural/more general issues with which they deal.

Hypothesis 1b: Decisions with higher authority score are cited for their procedural/more general issues with which they deal.

Hypothesis 2a: Decisions with low indegree centrality are cited for their substantive issues with which they deal.

Hypothesis 2b: Decisions with low authority score are cited for their substantive issues they with which they deal.

\section{ANALYSIS AND DISCUSSION}

While being aware of the thin divide between what may be categorized as substantive and procedural law-related reason for which a decision was

${ }^{43}$ Authority scores of individual decisions are related to the whole network of decisions in the corpus referred to above. 
cited, for the purpose of this paper, we understand the procedural/substantive divide as follows.

Since the substantive law is a label related to rights and obligations of individuals (subjects of law), substantive law usually refers to actual claims of individuals. In our corpus of asylum-related decisions, these would comprise of interpretation of rights or reasons to grant asylum). Procedural law, on the other hand, comprises of rules governing the given procedure to test and protect these claims. In our asylum-related corpus, the procedural elements manifested in admissibility issues, burden of proof or competence of a body). In addition, some of the reasons for which the decisions were cited were somewhere between procedural and some sort of general nature, such as asking about the purpose of a discussed concept. Since these issues could not be classified as being of substantive law nature, and because of their conceptual closeness to the procedural baselines, we have included these borderline issues into the procedural category, which we label as "procedural/general".

Therefore, we have classified the reasons for which a decision was cited in another decision of the chain as either

- Procedural/general (comprising situations as admissibility of claims, burden of proof, obligations of a state body when making a decision, competence of a body or purpose of a concept);

- Substantive (interpretation of basic rights, interpretation of specific positive law concepts, application of specific requirements on a practically identical situation);

- Inconclusive (comprising situations where the court cited a decision for more than one reason). ${ }^{44}$

To differentiate between high and low indegree and high and low authority score, we have set up the lines as outlined in Table 4, taking into consideration the variation across these indicators.

44 It must be noted that in law, it is not always easy to clearly categorize the reason for which a decision was cited as either of procedural or substantive nature. Even in cases where the decision itself was rather procedural (because it was not per se a decision on the merit of the case, just a decision on inadmissibility of the claim), the reason for which it was cited might not be related to the 'ratio decidendi' of the case, because it could have been some marginal issue the court opened when justifying the decision. 


\begin{tabular}{|c|c|c|}
\hline Categorization & Indegree & Authority score \\
\hline High & $>50$ & $>1,3 \cdot 10^{-6}$ \\
\hline Mid-range & 11 to 49 & $1,0 \cdot 10^{-8}$ to $3,8 \cdot 10^{-7}$ \\
\hline Low & $<10$ & $<8,2 \cdot 10^{-9}$ \\
\hline
\end{tabular}

Table 4: Distribution of high/mid-range/low indegrees and authority scores

After leaving out decisions of Level 5 (our citation chains did not go beyond Level 5), thirteen decisions were categorized as having high indegree centrality, twenty-five decisions were categorized as having low indegree centrality, while ten decisions were categorized as having high authority score and twelve as having low authority score.

\section{Indegree centrality vs. Context of citation}

Although the lines between these categories are rather blurred and debatable and although it is to be expected that the decision-making of apex courts in the analyzed situations would be predominantly of procedural/general nature, ${ }^{45}$ we have identified nine situations where a judicial decision was cited predominantly as an argumentative support for a substantive law related claim.

Only six of the decisions cited in substantive circumstances were categorized as having low indegree and no decision with high indegree centrality was cited for substantive law reasons.

Unsurprisingly, out of forty-four situations in which a decision could be cited in our chains thirty-one citations were used to support procedural/general arguments the court makes in the rationale of its decision. Out of the thirty-one, sixteen citations led to decisions with high indegree centrality, seven to mid-range and eight to low indegree centrality decisions.

\section{Authority score vs. Context of citation}

We have found out that in 16 cases the reason a high authority score decision is cited is of procedural/general nature; this means that all the decisions whose authority score we have categorized as high are cited only for procedural/general reasons. In seven cases, a decision categorized as having low authority score was cited for procedural/general reasons. Only two decisions categorized as having low authority score were cited for

45 As further discussed below, most of the decisions of Czech apex courts are those deciding the case is inadmissible. The reasons for these decisions are grounded in procedural reasons. Hence the abundance of procedural/general decisions available. 
their substantive law considerations. In all the other instances (5) where a decision was cited for a substantive law reason the decision was categorized as having mid-range authority score.

Abundance of procedural/general reasons for citation

It is clear that in a significant number of cases (31) the reason for which a decision was cited was a procedural/general one. When it comes to apex court decision-making in the Czech legal system, this is not surprising: overviews of decision-making of the apex courts in the Czech Republic show that a significant amount of the decisions of these courts are in fact decisions on inadmissibility of the claim, ${ }^{46}$ therefore being decisions falling into our procedural/general category. Even in situations where the courts would consider the similarity of the cases' facts, the facts of decisions containing considerations of procedural/general nature would be assessed on a higher level of abstraction. It cannot be ruled out, that in these situations - and in accordance with basic legal principles (such as that of due process) - the relevant facts even should be judged on a higher level of abstraction, disregarding more detailed factual differences. Some of these cases may in fact not really be judged as omitting to consider the similarity of facts, but simply working with the facts on a more abstract and general level.

We can observe this situation in particular in the Asylum 1, 2 and 3 chains: Asylum 1 Level 1 decision is always cited because it is specifying the meaning of a phrase/concept closely related to admissibility of a claim; Asylum 2 Level 1 decision is always cited for one particular feature related to procedural matters - identification of the right provision of the procedural code that applies to a particular case of admissibility of a claim; Asylum 3 Level 1 decision is always cited as an example of settled case-law of the way the points of a court claim should be formulated. On a very abstract level, all the Level 2 decisions' facts are comparable to the respective Level 1 decisions (e.g. in Asylum 2 chain, all the Level 2 decisions dealt - apart from other issues - with an incorrect designation

46 In 2019, Supreme Administrative Court decided 1381 out of 3880 claims were inadmissible, while Constitutional Court decided 409 out of 430 claims were inadmissible. See Statistical Overviews available $\mathrm{cls}=$ StatistikaNewAlldata $=1$ statoid=4year $=2019 \mathrm{menu}=190>$ at <http://nssoud.cz/Main2col.aspx? $<$ https://www.usoud.cz/fileadmin/userupload/ustavnisoudwww/Statistika/VSA2019.pdf.> Even though the decisions on inadmissibility are of procedural nature, they may still be picked up in later decision-making where a court's opinion on individual reasons of inadmissibility is found useful. 
of points of claim). On a more detailed level, however, the facts of the Level 2 decisions would have to be judged as dissimilar. In Asylum 2 and Asylum 3 chains, Level 2 decisions were not even made in asylum matters. Asylum 1 chains (especially the Asylum 1 max chain), however, seem to be a slight exception to this rule.

Asylum 1 max chain is one of the most thematically coherent citation chains in our sample: Level 5 to Level 2 decisions were made in factually very similar situations: asylum cases of nationals of Kazakhstan, who claim to be persecuted in their country of origin for their practice of so-called Pure Islam. Similar level of factual cohesion may only be partially seen in the Asylum Mean chain (where all the decisions are related to situations of legal expulsion of a person, but the reasons for it differed) and Asylum Median chain (all the decisions are related to situations of legal expulsion of a person as well as one particular circumstance - interpretation of the concept of "a relationship analogical to family relationship").

The Asylum Median chain is notable for one additional feature: all the decisions have very low indegree centrality (ranging between 1 and 4) and as in the only chain in out sample, all the decisions were cited for substantive law reasons.

While it seems that decisions with higher indegree centrality are cited for their procedural/general reasons (hypothesis 1a) and that decisions with higher authority score are cited for their procedural/more general reasons (hypothesis $1 b$ ), our experiment's data seem inconclusive when it comes to hypotheses $2 \mathrm{a}$ and $2 \mathrm{~b}$. Although in no situation was a high indegree/high authority score decision cited for substantive law reasons, the indegree centrality as well as the authority score of the decisions cited for substantive law reasons varied greatly: 1 to 44 in case of indegree centrality of cited decision; between $1,10^{-11}$ and $1,10^{-7}$ in case of authority scores of cited decisions. ${ }^{47}$

Nevertheless, the only case where a whole chain of decisions was cited for substantive law reasons AND had low indegree centrality was the Asylum Median chain, consisting of decisions that were cited truly scarcely. However, their authority scores were predominantly in the mid-range we specified above.

47 To compare, authority score of the most cited decision in our corpus - decision of Czech Constitutional Court no. IV. ÚS 73/03 has authority score 0,13 and indegree centrality 6112. 
We believe that our results may be interpreted in light of what the theory suggests about the continental use of case-law: while the whole system may at surface exhibit similar tendencies as a precedential system, ${ }^{48}$ the similarities may very well be based on very different reasons ${ }^{49}$ which may further dispute the automatic borrowing of operationalization of "importance" of a decision by means of their citation in another decision. ${ }^{50}$

Furthermore, when analyzing the decisions themselves, the guiding motivation to use past case-law in judicial argumentation may be described more as a call to coherence rather than a call to a precedent, even in situations where the court itself uses the word 'precedent' when citing another decision. ${ }^{51}$ These 'precedential' situations are not always the core (to borrow a term from the doctrine of precedent - the ratio decidendi) of what the court dealt with. Especially in situations where the cited decision is of high indegree centrality or high authority score, the reason for which it is cited is often a marginal one in the whole of the rationale. However, it must be noted that within the Czech legal system what is 'marginal' in an apex court decision's rationale is rather relative. The court pieces its argument from different points of view, identifies various legal and argumentative points that add up to the justification of the final decision, drawing upon previously published legal opinion of itself or another apex court in each of these points. Consequently, this leads to situations where a single decision refers to many other past decisions, sometimes to support the ratio decidendi, but also to support general claims related to the competence of the court itself. ${ }^{52}$ In a setting where each piece of argumentation starting with competence and procedure tends to be supported by past decisions, it is inevitable that these decisions will score higher in various network metrics.

Moreover, we believe that the main reason why past decisions are cited for procedural/general reasons even in situations where the particular

48 See Derlén and Lindholm (2017) op. cit., pp. 647-686 or Harašta, Smejkalová, Novotná et al. (2020) op. cit.

49 Loughlin. M. (2010) Foundations of Public Law. Oxford: OUP, p. 313.

50 As already mentioned above, the automatic borrowing of this operationalization used originally in research in legal systems following the doctrine of binding precedent has been critically discussed by Smejkalová (2020) op. cit., pp. 39-56.

51 See decision Asylum 1 max Level 2 (Supreme Administrative Court decision no. 3 Azs $89 / 2007-68)$.

52 The decision with the highest indegree as well as a decision with the highest authority score in the corpus of decisions we work with is being cited for a simple claim about the competence of Constitutional Court of the Czech Republic. See Constitutional Court's decision No. IV. ÚS 73/03 referred to above. 
reason is not anywhere near the ratio decidendi of a case may be to simply provide a symbolical proof of coherence with the rest of the decision-making practice, most often based on similarity of legal claims, ${ }^{53}$ or, occasionally, to reason by analogy. The individual choice to cite a judicial decision would then be guided by the principle of optimal relevance: 'the greater the cognitive effect achieved, and the smaller the mental effort required, the more relevant this input will be (...) at the time ${ }^{54}$ and in the particular context, therefore influenced by numerous external and internal factors. ${ }^{55}$ This human tendency, thoroughly explained by pragmatic theories of relevance, ${ }^{56}$ when assessed in the context of judicial decision making, results in using a reference to a past decision in support of the court's decision only if the result is better than what it would have been without it, and using the decision (including finding it, analysing it etc.) is worth the effort.

Therefore, we believe that the more interesting results of our study are actually those that seem inconclusive in relation to the tendencies listed as hypotheses $2 \mathrm{a}$ and $2 \mathrm{~b}$. It was rather clear in the texts of this very limited sample of decisions we worked with that while the court seemed to care about citing a decision to support its claim, it was not always necessarily one with the most prominence in the legal system. We have observed situations where the cited decision in our chains was one made by the same panel of judges a couple of months earlier (such as when Asylum Mean Level 3 cites Asylum Mean Level 2) as well as distinguishing a truly 'precedential' decision in a very similar situation (such as when Asylum 1 max Level 5 decision cites Asylum 1 max Level 4 decision).

We believe that these findings are telling with respect to the fluid and inconsistent way the normative nature of case law in the Czech legal system is treated. When there is no clear rule to guide the court when and how should it cite past judicial decisions, the guiding mechanism will be that of optimal relevance: as long as citing past decisions is not reprimanded and

53 Feldman, M. S., March, J. G. (1981) Information in Organizations as Signal and Symbol. ADMIN. Scl. Q, 26(2), p. 171-186, or in Czech context Smejkalová, T. (2013) Odkazy na soudní rozhodnutí a symbolická hodnota informace. Jurisprudence, 8: pp. 3-9.

54 Wilson, D. (2016) Relevance Theory. In: Huang, Y. (ed.) Oxford Handbook of Pragmatics. Oxford: OUP, p. 87.

55 For more details on how to understand an optimally relevant choice in citing past case law, regardless of legal system in question see Smejkalová (2020) op. cit.

56 Sperber, D. and Wilson, D. (1995) Relevance: communication and cognition. 2nd Edition. Oxford: Blackwell. 
as long as it brings the sought for results (i.e. a well-reasoned decision coherent with the rest of the legal system) and as long as the decision is accessible the court will continue to do so. To what extent does this practice constitute a normative practice with normative expectations is yet another question.

\section{CONCLUSION}

In our research, network analysis and network metrics of indegree centrality and authority score were used as a part of mixed method approach, complemented by analysis of the texts of thus chosen decisions. We have used network analysis to construct the chains to further analyze the decisions by traditional means - textual analysis - mainly to avoid bias in choosing decisions to which - or from which to construct chains of citations. In this regard, we follow a similar line of research as Olsen and Kücküksu ${ }^{57}$ did when analyzing a set of European Court of Human Rights' decisions.

Our limited study's results seem to suggest that the expectation of decisions with high indegree centrality and/or high authority score would be cited for their procedural or other general reasons might be the correct one. They are, however, not conclusive as to the opposite of this claim as decisions with lower indegree centrality and low authority score in our sample were not necessarily cited for the substantive law reason, since only two out of nine decisions categorized as having low authority score were actually cited for these reasons.

While our results must be treated as limited proof-of-concept case study, we believe that its results are conducive with the fact that the normative role of case law in the Czech legal system is not a settled matter, which makes the actual citation environment in continental legal setting more complex than our hypotheses suggest. However, present methodological approach seems capable to be highly useful in further exploring the normative nature of judicial decisions in non-precedential legal settings.

Additionally, our research approach may contribute to practical use of this type of citation analysis as well, since citation analysis is commonly used in legal recommendation systems. Wagh and Anand provided a study

57 Olsen, H.P., Kücküksu, A. (2017) Finding hidden patterns in ECtHR's case law: On how citation network analysis can improve our knowledge of ECtHR's Article 14 practice. International Journal of Discrimination and the Law. 17(1): pp. 4-22. 
proving higher similarity of the decisions connected with citations than the decisions similar according to the cosine similarity. ${ }^{58}$

On the other hand, our conclusions suggest that not all the cited decisions are relevant when it comes to considering the legal issue. Therefore, a recommendation system based only on the citations might retrieve a set of decisions only with low precision. Thus, it requires additional post-processing which makes the precise judicial decisions retrieval time consuming. To achieve higher precision of retrieved decisions, we suggest including a subsequent semantic processing to distinguish between different court decisions cited for different legal reasons. We believe that a combination of a citation analysis and semantic similarity may lead to a more efficient and more precise judicial decisions retrieval.

\section{LIST OF REFERENCES}

[1] Agnoloni, T., Pagallo, U. (2015) The case law of the Italian constitutional court, its power laws, and the web of scholarly opinions. In: ICAIL'15: 15th International Conference on Artificial Intelligence and Law, pp. 151-155.

[2] Agnoloni, T. Pagallo, U. (2015) The Power Laws of the Italian Constitutional Court, and Their Relevance for Legal Scholars. In: Legal Knowledge and Information Systems. pp. $1-10$.

[3] Araszkiewicz, M., Šavelka, J. (eds.) Coherence: Insights from Philosophy, Jurisprudence and Artificial Intelligence. Heidleberg: Springer.

[4] Black, R.C. and Spriggs, J.F. II. (2013) The Citation and Depreciation of U.S. Supreme Court Precedent. Journal of Empirical Legal Studies, 10(2), pp. 325-358.

[5] Bobek, M., Kühn, Z. et al. Judikatura a právní argumentace. 2nd edition. Praha: Auditorium, 2013.

[6] Brandes, U. and Erlebach, T. (eds.) (2005) Network Analysis. Methodological Foundations, Heidelberg: Springer.

[7] David, L. (2008) Co je precedent v rozhodnutích českých civilních soudů? In: Dny práva-2008-Days of Law. Brno: Tribun EU [online]. 2008 [accesseed 1.2.2013]. Available from http://www.law.muni.cz/sborniky/dp08/files/pdf/prteorie/david.pdf.

\footnotetext{
58 Wagh, R., \& Anand, D. (2017). Application of citation network analysis for improved similarity index estimation of legal case documents: A study. 2017 IEEE International Conference on Current Trends in Advanced Computing (ICCTAC), 1-5. https://doi.org/10.1109/ICCTAC.2017.8249996.
} 
[8] Derlén, M. and Lindholm, J. (2017) Peek-a-Boo, It's a Case Law System! Comparing the European Court of Justice and the United States Supreme Court from a Network Perspective. German Law Journal, 18(3), pp. 647-686.

[9] Derlén, M. and Lindholm, J. (2014) Goodbye van Gend en Loos, Hello Bosman? Using Network Analysis to Measure the Importance of Individual CJEU. Judgments. European Law Journal, 20(5), pp. 667-687.

[10] Derlén, M. and Lindholm, J. (2015) Characteristics of Precedent: The Case Law of the European Court of Justice in Three Dimensions. German Law Journal, 16(5), pp. 1073-1098.

[11] Feldman, M. S., March, J. G. (1981) Information in Organizations as Signal and Symbol. ADMIN. Scl. Q, 26(2), p. 171-186.

[12] Fowler, J.H., Johnson, T.R., Spriggs, J.F., Jeon, S., Wahlbeck, P.J. (2007) Network Analysis and the Law: Measuring the Legal Importance of Precedents at the U.S. Supreme Court. Political Analysis, 15(3), pp. 324-346.

[13] Fowler, J. and Jeon, S. (2008) The Authority of Supreme Court precedent. Social Networks, 30, pp. 16-30.

[14] Frankenreiter, J. (2017) Network Analysis and the Use of Precedent in the Case Law of the CJEU - A Reply to Derlén and Lindholm. German Law Journal, 18(3), p. 687- 693.

[15] Harašta, J., Novotná, T., Šavelka, J. (2020) Citation Data of Czech Apex Courts. : arXiv:2002.02224, ISSN 2331-8422, available from: https://github.com/czech-case-lawrelevance/czech-court-citations-dataset.

[16] Harašta, J., Smejkalová, T., Novotná, T. et al. (2020) Citační analýza judikatury. Praha: Wolters Kluwer (in print).

[17] Harvánek, J. et al. (2008) Teorie práva. Plzeň: Vydavatelství a nakladatelství Aleš Čeněk.

[18] Hitt, M. (2016) Measuring Precedent in Judicial Hierarchy. Law and Society Review, 50(1): pp. 57-81.

[19] Kleinberg J.M. (1998) Authoritative sources in ahyperlinked environment. In Proceedings of ACM-SIAM Symposium on Discrete Algorithms, p. 668-677.

[20] Kühn, Z. (2001) Nová koncepce normativity judikatury obecného soudnictví na pozadí rozhodnutí Ustavního soudu. Právní rozhledy, (6), pp. 265 - 269.

[21] Loughlin. M. (2010) Foundations of Public Law. Oxford: OUP. 
[22] MacCormick, N., Summers, R. S. (eds.) (1997) Interpreting Precedents. A Comparative Study. Dartmouth: Aldershot.

[23] Olsen, H.P., Kücküksu, A. (2017) Finding hidden patterns in ECtHR's case law: On how citation network analysis can improve our knowledge of ECtHR's Article 14 practice. International Journal of Discrimination and the Law. 17(1): pp. 4-22.

[24] Petersen, N. and Towfigh, E. V. (2017) Network Analysis and Legal Scholarship. 18 German Law Journal, 18(3), p. 695-700

[25] Polčák, R. (2012) Internet a proměny práva. Praha: Auditorium, p. 228-232.

[26] Smejkalova, T. (2019) Judikatura, nebo precedens? Právník, 158(9), pp. 852-864.

[27] Smejkalová, T. (2013) Odkazy na soudní rozhodnutí a symbolická hodnota informace. Jurisprudence, 8: pp. 3-9.

[28] Smejkalová, T. A Matter of Coherence. In: Araszkiewicz, M., Myška, M., Smejkalová, T., Šavelka, J., Škop, M. (eds.) Law and Literature. Argumentation 2012 Workshop Proceedings. Brno: Masarykova univerzita, pp. 31-44.

[29] Smejkalová, T. (2020) Importance of judicial decisions as a perceived level of relevance. Utrecht Law Review, 16 (1): pp. 39-56. doi:10.36633/ulr.504

[30] Wagh, R., \& Anand, D. (2017). Application of citation network analysis for improved similarity index estimation of legal case documents: A study. 2017 IEEE International Conference on Current Trends in Advanced Computing (ICCTAC), 1-5. https://doi.org/10.1109/ICCTAC.2017.8249996.

[31] Whalen, R. (2013) Modelling Annual Supreme Court Influence: The Role of Citation Practices and Judicial Tenure in Determining Precedent Network Growth. In: Menzes, R., Evsukoff, A., Gonzales, M.C. (eds.) Complex Networks. Studies in Computational Intelligence. Berlin, Heidelberg: Springer, pp. 169-176.

[32] Wilson, D. (2016) Relevance Theory. In: Huang, Y. (ed.) Oxford Handbook of Pragmatics. Oxford: OUP, p. 79-100.

[33] Winkels, R. and Ruyter, J. (2012) Survival of the Fittest: Network Analysis of Dutch Supreme Court Cases. In: Palmirani, M. et al. (eds.) AICOL Workshops 2011. Heidleberg: Springer Verlag, pp. 106-115. 